\title{
Analysis of companies' bankruptcy in Poland as compared with the cost of protection under trade credit insurance
}

\author{
Robert Dankiewicz \\ Department of Finance, Banking and Accounting, \\ Rzeszón University of Technology, \\ Poland \\ rdankiew@prz.edu.pl \\ ORCID 0000-0003-3453-2892
}

\begin{abstract}
The phenomenon of company bankruptcy is in fact an inherent element of market economy functioning which is due, among other things, to the high level of competition on the market. Considering the fact that the vast majority of companies conduct their activities with the use of trade credit, there is a significant risk of financial problems when creditors fail to pay their receivables in a timely manner. The purpose of the paper is to analyze the phenomenon of bankruptcy in Poland, and to identify the relationship between the scale of bankruptcy and the cost of securing receivables with the use of trade credit insurance. The research that enabled to achieve the set purpose was conducted on a sample of 8223 entities operating in Poland in various sectors of economy. The study was carried out in two stages by means of basic descriptive statistics, and the results were analyzed by means of the Kruskal Wallis ANOVA test and Spearman's rank correlation. The research has shown that there was a high level of dependence between the change in the amount of gross written premium on trade credit insurance and the number of bankruptcies in the construction sector.
\end{abstract}

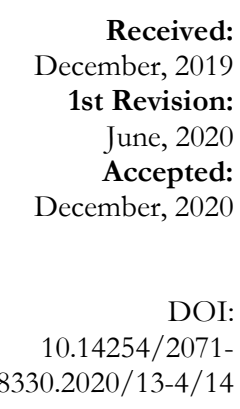

$8330.2020 / 13-4 / 14$

Keywords: bankruptcy risk, bankruptcy, trade credit insurance.

JEL Classification: G22, G32, G33

\section{INTRODUCTION}

Bankruptcy is an integral part of companies' functioning under the conditions of market economy. It results from natural processes that derive from competition as a result of which unprofitable units are forced to liquidate, thus creating a space for those that are more effective in using limited resources. However, it seems inappropriate to analyze this phenomenon in isolation from its negative consequences which affect creditors, suppliers and employees, thus often affecting a large part of the community at the same time. That is why, it is so important to carry out research in the field of bankruptcy forecasting and to look for dependencies with other parameters characterizing the market, which may be a helpful barometer in 
identifying the directions of changes within the existing processes (Wojcik \& Ciszewska-Mlinarič, 2020). Trade credit insurance premiums are one of the potential barometers of an economic climate. The vast majority of available scientific publications refer only to the essence of credit risk, its identification and measurement of the consequences of its implementation (ICISA, 2015; Bera, 2005). A relatively few studies have included the analyses aimed at answering the question - can loan insurance be something more than just a tool used in risk management processes (Dankiewicz, 2020). General conclusions do not provide a full picture of changes in receivables turnover, therefore, they should take into account specific variables such as the industry where the company is operating (Prasad, 2016).

Only taking these specific variables into account would make it possible to develop tools useful for the ongoing monitoring of the state of the economy. The identified possibilities of early detection of threats in most cases make it possible to take corrective actions quickly, which is of interest to both those at risk of bankruptcy and their market environment. Introduction of effective tools for forecasting the areas of the economy that are particularly threatened by bankruptcy allows minimizing losses. In addition, these tools can act as early warning systems for insolvency, thus identifying the initial stages of impending crises. The purpose of this paper is to analyze and evaluate the phenomenon of bankruptcy in Poland, and to identify the relationship between the scale of bankruptcy and the cost of receivables protection with the use of trade credit insurance.

\section{LITERATURE REVIEW}

The issue of bankruptcy of companies operating in various sectors has been widely described in the literature. When considering it is very important to clarify what the bankruptcy is. In the literature, it is often indicated that bankruptcy of businesses is a concept that in some way combines the terms of bankruptcy and insolvency (Siciński, 2019). It is usually indicated that bankruptcy is a phenomenon that is in some way a combination of not only insolvency and bankruptcy, but also broadly understood financial difficulties that occur in a given company (Piesse et. al., 2006). In turn, according to Mainardes et al. (2020), bankruptcy is defined as a situation where the company is financially unstable. Moreover, Aleksanyan \& Huiban (2016) indicate that bankruptcy means that an enterprise is unable to pay its liabilities, which in turn may be regarded as a sign of the inability of the company to adjust to the conditions imposed by the competition. It is also worth noting that the risk of the company bankruptcy in the environment may mean that the company will not be able to meet all its obligations (Bărbuț ă-Miș u \& Madaleno, 2020).

The risk of companies bankruptcy is one of the main types of risk that accompanies business activity. The reasons for this phenomenon can be found in many factors. Research conducted by scientists from around the world shows that the emergence of a financial crisis may have a significant impact on an increase in the risk of bankruptcy of enterprises (Mackevičius et al., 2018), while others seek links between the scale of the risk of a company insolvency and its age (Kücher et al., 2020). However, one should note that one of the most common reasons that lead to a corporate failure is poor financial risk management and bad debt management (Kristanti et al., 2019). Researchers also agree that the main determinants of bankruptcy risk are liquidity, profitability and leverage, and these factors are in turn widely used as variables in a variety of bankruptcy forecasting models (Lukason \& Camacho-Miñano, 2019). The complex view on important financial ratios influencing the stable development of enterprises and thus the financial health and competitive position is presented in the previous papers (Kovacova et al. (2019); Pointer \& Khoi, 2019; Kliestik et al. (2020). Companies in developed countries have mixed capital structures, while companies in less developed countries are largely dependent on bank loans and credits. Interest rates and bond yields exercise important effect on company's borrowing decision (Gaspareniene et al., 2019; Redo, 2013). 
As already earlier, one of the most important factors that can inevitably lead to the bankruptcy of a business is poor management of financial risk and debt. Therefore, it is extremely important to analyze the phenomenon of bankruptcy in relation to the sources of financing enterprises' operations. The literature on the subject indicates that one of the main sources of short-term financing of enterprises is trade credit (Petersen \& Rajan, 1997). It boils down to providing financing by companies that do not deal with financing as their core business (García-Teruel \& Martínez-Solano, 2010; Wajda-Lichy \& Kawa, 2018; Redo \& Siemiątkowski, 2017). It is an agreement concluded between the supplier and the customer, where the customer has an option to purchase goods on credit, i.e. with a deferred payment date (Gyimah et al., 2020). (Staszkiewicz \& Szelagowska, 2019) research takes data from 32,614 companies from 43 European countries with the ultimate owners from 105 countries. The results suggest that the domestic owner is generally less risk-averse. (Xing, 2019) examines the risk decisions of private and public companies for research and development in a product differentiated mixed duopoly market. It compares market developments between Cournot and Bertrand competition model. The main findings are that public companies are always taking higher risks than private companies under Cournot model.

In times of intense competition and globalization of markets, the use of trade credit appears to be essentially essential to maintain business relationships and develop business, just as a supply chain financing itself is necessary to gain a competitive advantage (Pirttilä et al., 2019; Pattnaik et al., 2020). The undoubted popularity of a trade credit in economic practice can be connected with the fact that this method of financing may be an element of the company's competitive strategy. Therefore, it may encourage existing and new contractors to cooperate, and may also contribute to the reduction of transaction costs or an improvement of the control process quality in the enterprise (Ciżkowicz-Pękała, 2017; Chod et. al., 2019; Van Horen, 2004; Peura et. al., 2017; Stakanov \& Ukhova, 2020). The aforementioned effects of using the trade credit can obviously translate into the results of the activities conducted by enterprises. Numerous studies indicate the existence of a relationship between the use of a trade credit and financial results. It is shown that a trade credit depending on the country and its market specificity, as well as depending on the company itself, may increase the profitability of an enterprise (Juan Grau \& Reig, 2018), may improve cash flow (Kumaraswamy \& George, 2019), stimulate sustainable development of the individual (Huang et al., 2019), as well as eliminate the financial limitations of entities that struggle with such problems (Agostino \& Trivieri, 2019). Trade credit is one of the most flexible short-term sources of finance for businesses. A decision to increase or decrease trade credit is influenced by a company's financial performance. They use a sample of 958 European construction companies finding trade loans offered / received correlate directly with return on equity (Bărbuță-Mişu, 2018).

However, it should be noted that the use of a trade credit in economic practice may also have some negative consequences, particularly in the situation when problems arise with the payment of obligations by contractors. In such the case, payment gridlocks may occur, which in turn may lead to bankruptcy. Therefore, the issue of bankruptcy of companies should not be considered only from the point of view of the company, but also its stakeholders, i.e. employees, investors, creditors, consumers, and even the society (Khan Ajaz et al., 2020). One of the methods of minimizing the negative effects of a situation when contractors are unable to meet their obligations is the use of trade credit insurance. Trade credit insurance protects the lender against the buyer's default risk, which may arise due to commercial and political risks, so the insurers mainly cover the short-term commercial risk (Lezgovko \& Jakovlev, 2017). It should be noted, however, that due to its specific nature, trade credit insurance is dependent on the macroeconomic situation in the industry, which makes them extremely sensitive to any changes in business cycles, which in turn significantly increases their susceptibility to macroeconomic risk (Lisowski, 2014). However, as I. Kwiecień (2010) points out, when it comes to corporate management standards, the decision to choose insurance as 
an instrument of risk management should be supported by an analysis of the risk occurring in the company's environment.

Research shows that trade credit insurance, in addition to protecting the supplier against the risk of insolvency, may also be a form of export promotion (Polat \& Yeşilyaprak, 2017). This form of credit risk management also guarantees protection against the negative consequences of the debtor's bankruptcy (Kowalczyk-Rólczyńska, 2013). Therefore, it is one of the best methods of protection against financial problems on the side of the debtor, which could also cause some problems for the loan provider. Although the issues related to bankruptcy of enterprises, such as its causes and effects, have been widely described in the literature on the subject, there are no studies that would address this issue with trade credit insurance, and especially with the costs of protection under this type of insurance. Therefore, this paper fills this gap by providing information on the scale of bankruptcy in Poland in relation to the cost of trade credit insurance.

\section{METHODOLOGY}

The study covered companies based in Poland, operating in various sectors of the economy. The analysis of bankruptcy and the key areas of its occurrence were based on historical data for 2009-2018, obtained from the Central Statistical Office and the National Court Register. The method of examining documents with the interpretation of the data obtained and the method of analysis were used. The material included data presented in monthly (from 2012) and annual (before 2012) cycles, which is reflected in the analyzes and results from the method of data archiving by the above-mentioned institutions. Exploratory research was carried out on a sample of 8223 entities that declared bankruptcy in the period analyzed, and constituted all enterprises in the Polish market within the period. They were systematized taking into account the sections analyzed. The data relating to the parameters of the trade credit insurance market come from the reports of the Polish Financial Supervision Authority (premium written within trade credit insurance and RiskMan data (in relation to the average price for trade credit insurance).

In the paper the basic descriptive statistics were used to characterize the material. The meta-analysis method was applied. It was extended by a critical analysis of the literature on the subject and the available results of research conducted by scientific communities and practitioners dealing with issues related to the phenomenon of bankruptcy, trade credit insurance, in particular in relation to its importance in the processes of deferred payment risk management and the cost of insurance protection. The study was conducted in two stages. The first one refers only to the analysis of bankruptcy in Polish conditions, while the second one takes into account the relationship between the level of collected premiums and their amount on the trade credit insurance market and the scale of bankruptcy. The analyzes were based on numerical statements and the results of the ANOVA Kruskal Wallis test and the Spearman's rank correlation analysis. They allow assessing whether the relationship or differences between the selected features are statistically significant. The significance level of $\alpha=0.05$ was adopted for the research (it was assumed that: when $p<0.05$ there is a statistically significant relationship (marked with ${ }^{*}$ ); $\mathrm{p}<0.01$, there is a highly significant relationship $\left(^{* *}\right)$; $\mathrm{p}$ $<0.001$, there is a very high statistically significant relationship $(* * *)$.

The Kruskal-Wallis test is the non-parametric equivalent of the one-way analysis of variance. This test checks whether $\mathrm{n}$ independent samples are from the same population or from the population with the same median. Individual samples do not have to be of the same size. A maximum of 10 groups can be compared. The null hypothesis $(\mathrm{H} 0)$ states that the distributions are equal in the compared populations, i.e. that there are no differences or relationships between the variables. Spearman's rank correlation - this rank correlation takes values from the range [-1.1]. The interpretation is similar to the classical Pearson correlation coefficient, with one caveat: unlike the Pearson coefficient, which measures a linear relationship between 
variables and treats all other relationships as distorted linear relationships, the rank correlation shows any monotonic (including non-linear) dependence. The greater the value of the correlation coefficient, the greater the relationship between the variables. If the value is close to 0 , there is no relationship between the variables.

\section{EMPIRICAL RESULTS AND DISCUSSION}

Nowadays, when companies operate in an extremely dynamic environment characterized by enormous complexity and uncertainty of phenomena, the key issue is to identify risk areas, monitor the economic and financial situation on a current basis, and effectively forecast bankruptcy threats to react to them in advance. However, despite the awareness of the risks and often created strategies in the event of problems, the phenomenon of bankruptcy is now a natural element of the free market economy, occurring with varying intensity over time. In Poland, the scale of bankruptcy in individual years of the analyzed period was as follows: 2009 - 673 entities, 2010 - 691 entities, 2011 - 730 entities, 2012 - 941 entities, 2013 - 926 entities, 2014 - 822 entities, 2015 - 747 entities, 2016 - 805 entities, 2017 - 900 entities, 2018 - 988 entities. Per 100.000 entities operating in a given sector, the scale of the phenomenon in terms of sectors is presented in figure 1.

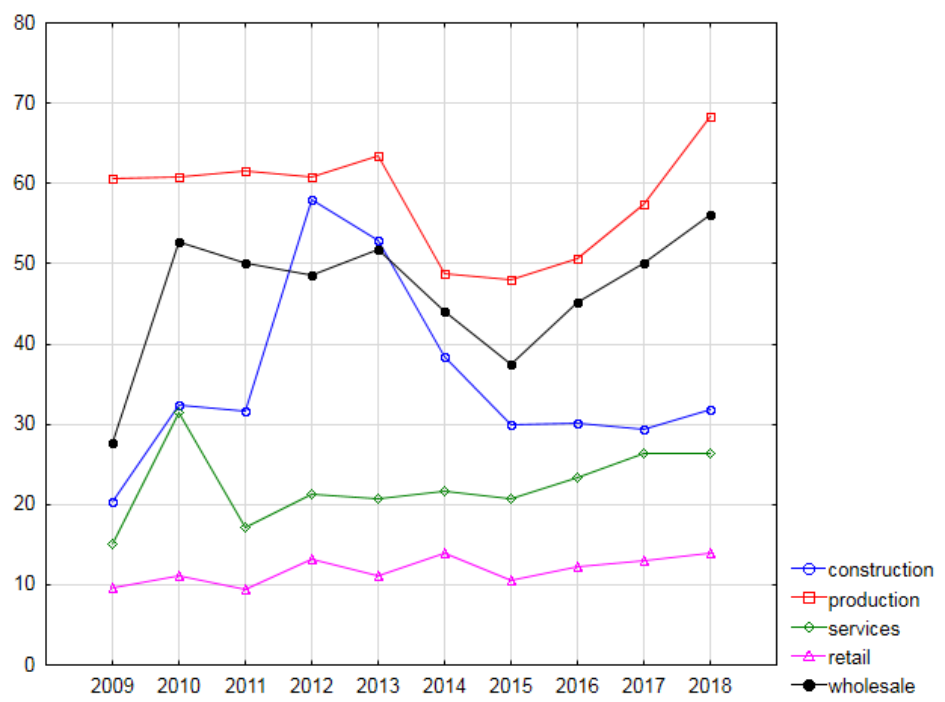

Figure 1. The number of companies that declared bankruptcy per 100 thousand businesses operating in a given sector

Source: Author's own study based on data from the Central Statistical Office and the Polish Financial Supervision Authority.

The chart shows that most companies declare bankruptcy in the manufacturing industry and it is on average 58 entities per year. The smallest number of manufacturing companies filed for bankruptcy in 2015 (48 entities) and the most in 2018 (68 entities) per 100.000 operating in this sector.

Retail sales companies fail the least - an average of 12 companies per 100.000. Historically, in this industry, in the years 2009 and 2011, 9 entities collapsed, and the highest value of the indicator was recorded in 2014, and there were 14 entities per 100.000 operating in this industry. The construction industry is the least stable in terms of the scale of bankruptcy. In its case, fluctuations are very large from 20 entities in 2009 per 100.000 operating entities to 58 in 2012, and the coefficient of variation is at the level of $32 \%$, and it is the highest among the analyzed industries. 
The analysis of the scale of bankruptcy in Poland proves that 2015 is the key year over the period analyzed. It is a breakthrough moment from which certain development trends appear in individual industries - production and wholesale record aggressive increases, in the case of services and retail sales a slight increase in companies declaring bankruptcy take place, while the construction industry is characterized by a stable level. The basic descriptive statistics of company bankruptcies in individual industries (per 100.000 entities) are presented in table 1.

Table 1

Basic descriptive statistics of company bankruptcies in particular industries

\begin{tabular}{|l|c|c|c|c|c|}
\hline & Mean & Minimum & Maximum & Standard deviation & $\begin{array}{c}\text { Variation } \\
\text { coefficient }\end{array}$ \\
\hline Construction & 35 & 20 & 58 & 11 & $32 \%$ \\
\hline Production & 58 & 48 & 68 & 7 & $12 \%$ \\
\hline Services & 22 & 15 & 31 & 5 & $21 \%$ \\
\hline Retail & 12 & 9 & 14 & 2 & $15 \%$ \\
\hline Wholesale & 46 & 28 & 56 & 8 & $18 \%$ \\
\hline
\end{tabular}

Source: Author's own study based on data from the Central Statistical Office and the Polish Financial Supervision Authority.

In order to detail the results, the descriptive statistics were also presented on a monthly basis (due to the fact that the data presented on a monthly basis were collected from 2012, the analysis period was limited to 2012-2018), which is presented in table 2.

Table 2

Basic descriptive statistics of company bankruptcies in individual industries in 2012-2018 on a monthly basis

\begin{tabular}{|l|c|c|c|c|c|c|c|c|}
\hline & Mean & Me & Min & Max & $\mathrm{Q}_{25}$ & $\mathrm{Q}_{75}$ & $\begin{array}{c}\text { Std. } \\
\text { dev. }\end{array}$ & $\mathrm{V}_{\mathrm{z}}$ \\
\hline $\begin{array}{l}\text { The number of failed companies in the } \\
\text { construction industry per 100.000 entities } \\
\text { operating in this sector }\end{array}$ & 3.2 & 3.1 & 0.4 & 7.0 & 2.2 & 4.1 & 1.3 & 39.9 \\
\hline $\begin{array}{l}\text { The number of failed manufacturing companies } \\
\text { per 100.000 entities operating in this sector }\end{array}$ & 4.8 & 4.7 & 1.9 & 8.9 & 3.8 & 5.6 & 1.2 & 26.3 \\
\hline $\begin{array}{l}\text { The number of failed service companies per } \\
100.000 \text { entities operating in this sector }\end{array}$ & 2.0 & 1.9 & 0.9 & 4.1 & 1.6 & 2.4 & 0.6 & 28.2 \\
\hline $\begin{array}{l}\text { The number of failed retailers per 100.000 } \\
\text { entities operating in this sector }\end{array}$ & 1.0 & 1.0 & 0.2 & 2.3 & 0.7 & 1.3 & 0.5 & 45.0 \\
\hline $\begin{array}{l}\text { The number of failed wholesalers per 100.000 } \\
\text { entities operating in this sector }\end{array}$ & 4.0 & 3.8 & 0.0 & 7.4 & 3.0 & 4.8 & 1.3 & 32.7 \\
\hline
\end{tabular}

Source: Author's own study based on data from the Central Statistical Office and the Polish Financial Supervision Authority.

Most companies declared bankruptcy in the manufacturing industry (on average, 4.8 per month per 100.000 entities operating in this industry). At the same time, it should be noted that this industry is the most uniform sector in terms of bankruptcy (it has the lowest coefficient of variation $\mathrm{Vz}=26.3 \%$ ). Minimum bankruptcy in a month was announced in the case of 2 companies out of 100.000 active entities operating in this sector (in October 2015) and a maximum of 9 companies per 100.000 active entities (in January 2013). 
The smallest number of entities that filed for bankruptcy was recorded in the retail sector. On average, only one company operating in this sector fails per 100.000 a month. At the same time, the attention is drawn to the highest coefficient of variation $\left(\mathrm{V}_{z}=45 \%\right.$ ), which means a large differentiation in bankruptcies of companies in this industry. The lowest value of the coefficient occurred in April 2015 (it was 0.2 entities per 100.000 companies operating in this sector), while the highest values of bankruptcies occurred in October 2018 (2.3 entities per 100.000 companies operating in this sector). In order to obtain a complete picture of the situation, the scale of the bankruptcy phenomenon in Polish conditions per 100.000 entities operating in the years 2012-2018 by industry are presented in figure 2.

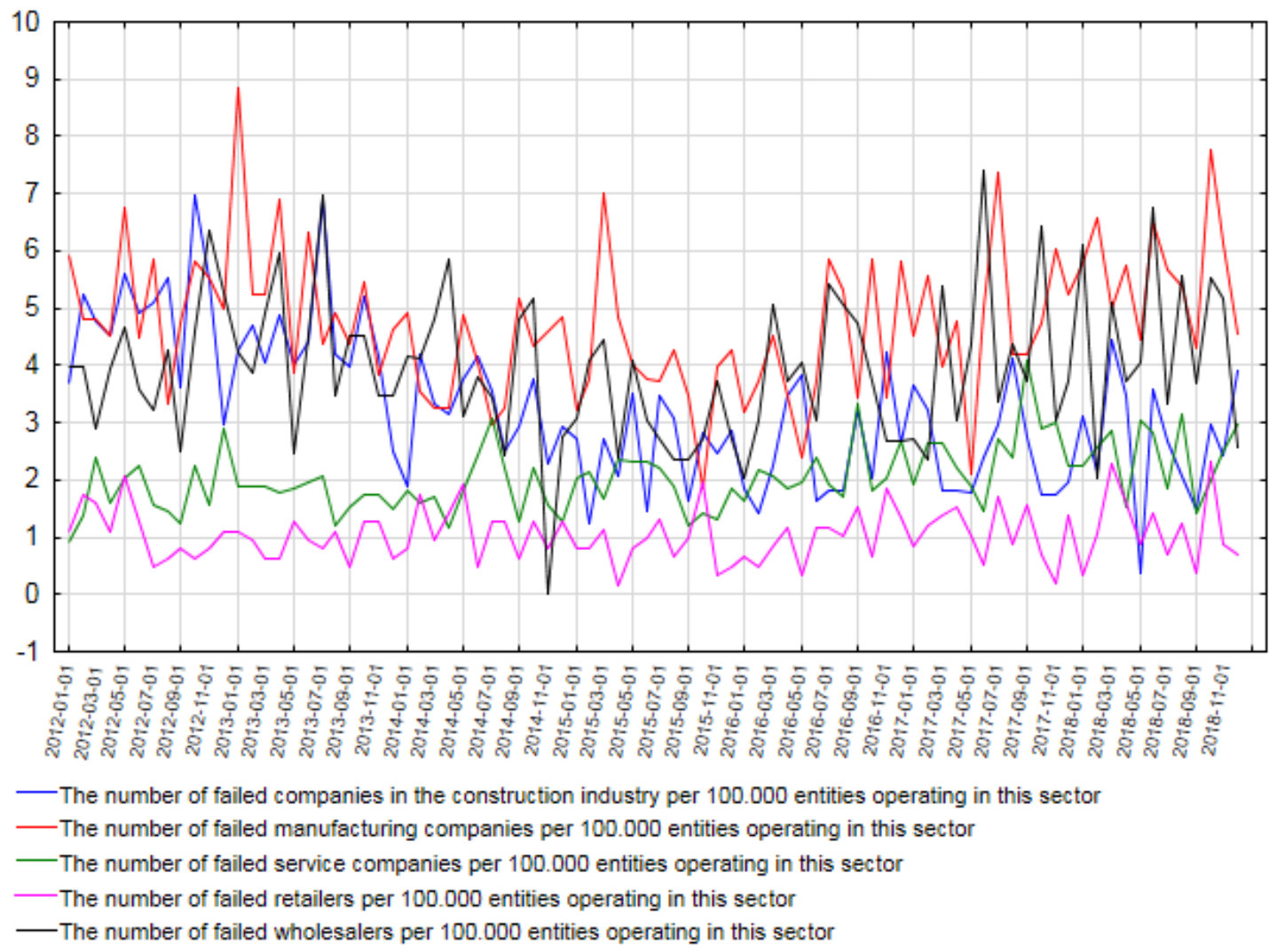

Figure 2. Time series of companies that declared bankruptcy in 2012-2018 per 100.000 entities operating in a given industry (monthly basis)

Source: Author's own study based on data from the Central Statistical Office and the Polish Financial Supervision Authority.

The analysis of the time series of companies that filed for bankruptcy in particular industries allows the conclusion that, with the exception of retail sales and service companies, the situation in the construction industry was relatively favorable in the period analyzed. In the years 2012-2016, a downward trend was noticeable, which reflects the prevailing market conditions. The breakthrough moment was 2016, which turned out to be the year when the current trend was broken and the beginning of a new one with a slight upward trend. The data on bankruptcies in the manufacturing sector are similar. More and more companies operating in services go bankrupt every year - here you can see a clear upward trend. The other two industries operating in retail and wholesale also have a similar bankruptcy nature. They are more or less maintained at a constant level, although since 2016 a slight increase in the number of companies failing in these industries has been recorded. 
During the analyzes, by means of the ANOVA Kruskal-Wallis test, it was checked whether the year had an impact on the average number of bankruptcies in particular industries. The results of the analyzes are presented in table 3 .

Table 3

Kruskal-Wallis ANOVA test results: one year compared to the number of bankrupt companies in individual industries

\begin{tabular}{|l|c|}
\hline & $\mathrm{p}$-value \\
\hline $\begin{array}{l}\text { The number of failed companies in the construction industry per 100.000 entities operating in this } \\
\text { sector }\end{array}$ & $0.0000^{* * *}$ \\
\hline The number of failed manufacturing companies per 100.000 entities operating in this sector & $0.0013^{* *}$ \\
\hline The number of failed service companies per 100.000 entities operating in this sector & $0.0037^{* *}$ \\
\hline The number of failed retailers per 100.000 entities operating in this sector & 0.6381 \\
\hline The number of failed wholesalers per 100.000 entities operating in this sector & 0.1694 \\
\hline
\end{tabular}

Source: Author's own study based on data from the Central Statistical Office and the Polish Financial Supervision Authority.

The results of the research prove that the differences in bankruptcies taking into account the year of occurrence appear in the case of companies operating in the construction industry $p<\alpha(p=0.0000)$, manufacturing companies $\mathrm{p}<\alpha(\mathrm{p}=0.0013)$ and service companies $\mathrm{p}<\alpha(\mathrm{p}=0.0037)$. In the construction sector, most companies failed in 2012 and 2013, and the least from 2015 to 2017. Most production companies went bankrupt in 2018 and 2013, and the least in 2014 and 2015. In the case of the service industry, the largest number of companies failed in 2017, and the least in 2013. The dispersion between the number of bankrupted companies on the example of two selected sectors, i.e. service and production, is presented in figure 3 .

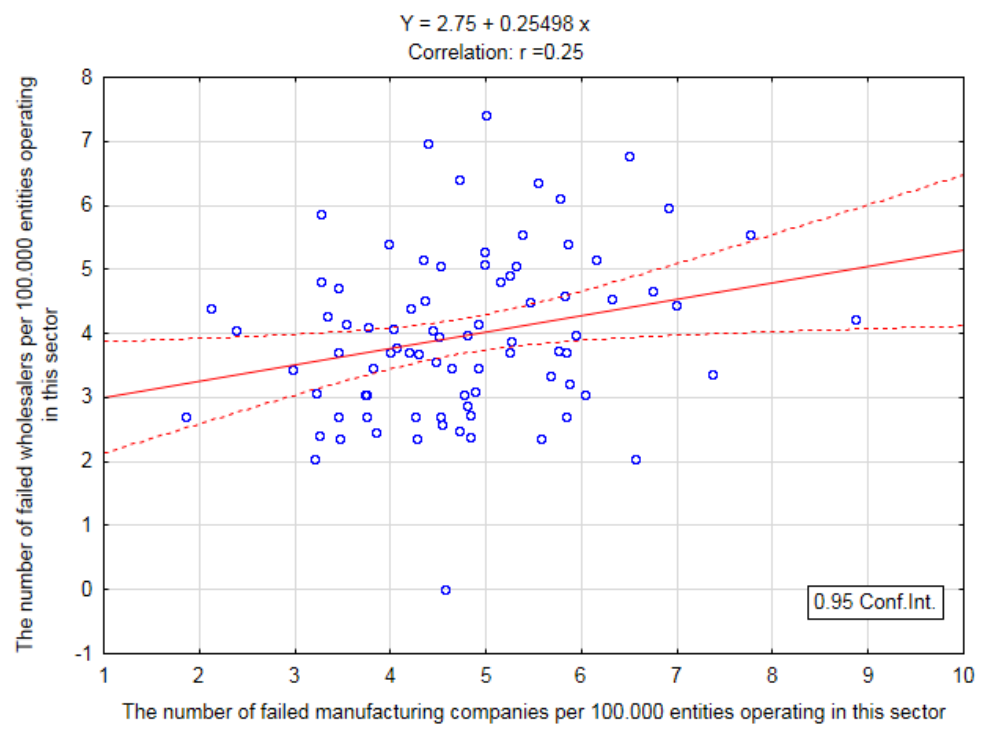

Figure 3. The dispersion between the number of failed companies in the service and manufacturing sectors

Source: Author's own study based on data from the Central Statistical Office and the Polish Financial Supervision Authority. 
In order to obtain a complete picture of the situation, figures 4, 5 and 6 present the number of bankrupt companies representing selected industries in comparison with the year of the research.

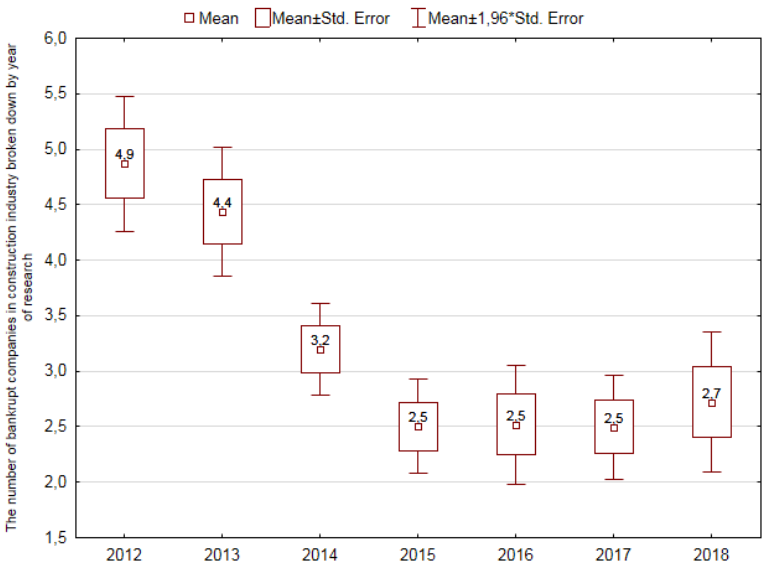

Figure 4. The number of bankrupt companies in construction industry broken down by year of research

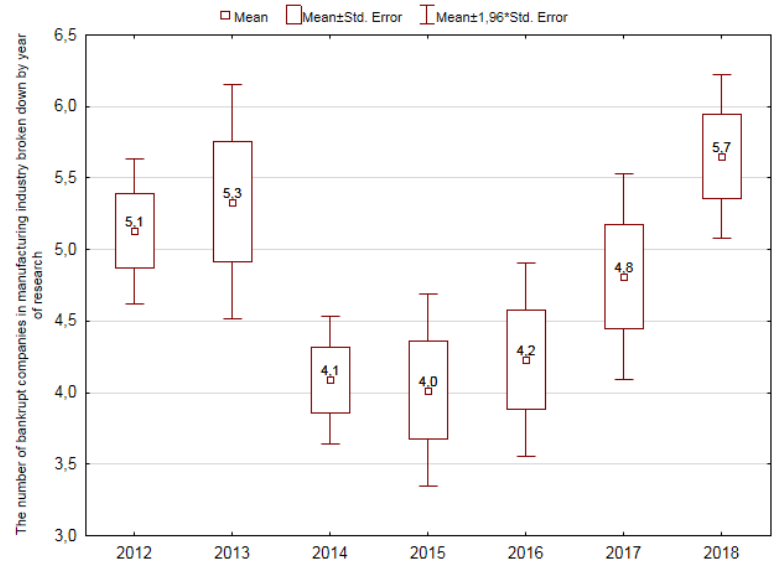

Figure 5. The number of bankrupt companies in manufacturing industry broken down by year of research

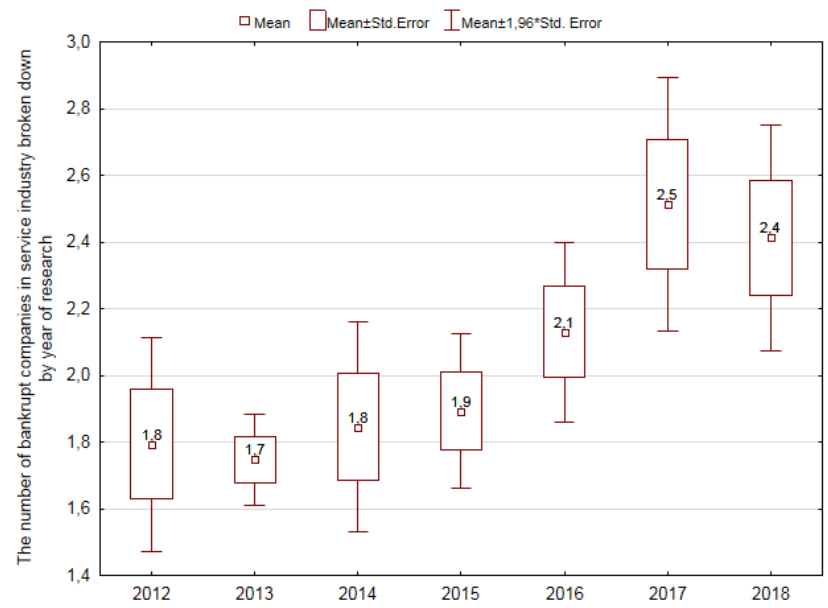

Figure 6. The number of bankrupt companies in service industry broken down by year of research Source: Author's own study based on data from the Central Statistical Office and the Polish Financial Supervision Authority.

At the same time, the relationships between the number of companies that failed in individual industries were verified. The research shows that the bankruptcy of manufacturing companies has a positive effect on the bankruptcy of companies in the wholesale industry. The correlation coefficient was 0.25 , which means a positive relationship, the relationship is linear, clear but low. Along with the increase in bankruptcies of companies in the manufacturing industry, the number of failed companies in the wholesale industry increases. The analysis shows that a very large relationship exists in the case of companies operating in the manufacturing industry and wholesale. Spearman's rank correlation coefficient is positive, which means that the more companies filed for bankruptcy in the manufacturing sector, the more went bankrupt in the retail sector. A similar relationship occurred in the case of retail and service sales, but here the relationship is slightly smaller and amounts to 0.64 . The matrix showing the correlation between the number of companies 
that declared bankruptcy in individual analyzed industries per 100.000 entities operating in a given industry are presented in table 4 .

Table 4

Correlation matrix between the number of companies that have declared bankruptcy in a given industry per 100,000 entities operating in a given industry

\begin{tabular}{|l|c|c|c|c|c|}
\hline & Construction & Production & Services & Retail & Wholesale \\
\hline Construction & 1 & 0.42 & 0.12 & 0.44 & 0.44 \\
\hline Production & 0.42 & 1 & -0.08 & -0.04 & 0.77 \\
\hline Services & 0.12 & -0.08 & 1 & 0.64 & 0.48 \\
\hline Retail & 0.44 & -0.04 & 0.64 & 1 & 0.19 \\
\hline Wholesale & 0.44 & 0.77 & 0.48 & 0.19 & 1 \\
\hline
\end{tabular}

Source: Author's own study based on data from the Central Statistical Office and the Polish Financial Supervision Authority.

Entrepreneurs more and more often see the potential consequences of risk, which may result in the necessity to declare bankruptcy in exceptional situations. At the same time they pay attention to the fact that they often do not have prepared formal action plans in the event of its implementation (AON, 2018). They see the growing demand for information and are aware that up-to-date and well-processed information is an important asset and the most important element of the decision-making process. Commercial risk resulting from deferred payment terms in transactions with customers is increasingly becoming the subject of insurance. The size of the Polish credit insurance market in 2009-2018 is impressed by the size of the premium collected in individual years together with the average premium rate in trade credit insurance is presented in table 5 .

Table 5

Gross premium written within class 14 (credit insurance) and average premium rates under trade credit insurance in Poland (2009 - 2018)

\begin{tabular}{|c|c|c|}
\hline Year & Gross premium in thousand PLN & $\begin{array}{c}\text { Average premium rates on the trade credit } \\
\text { insurance market in Poland (\%) }\end{array}$ \\
\hline 2009 & 460102 & 0.10 \\
\hline 2010 & 465144 & 0.16 \\
\hline 2011 & 544732 & 0.20 \\
\hline 2012 & 502609 & 0.175 \\
\hline 2013 & 526570 & 0.17 \\
\hline 2014 & 494537 & 0.175 \\
\hline 2015 & 403452 & 0.15 \\
\hline 2016 & 415664 & 0.135 \\
\hline 2017 & 389667 & 0.13 \\
\hline 2018 & 405785 & 0.15 \\
\hline
\end{tabular}

Source: Author's own study based on data from the Polish Financial Supervision Authority and RiskMan.

In order to obtain a complete picture of the situation in the trade credit insurance market in Poland in 2009-2018, the amount of the gross premium collected in the market within group 14 - credit insurance 
(figure 7) and the dispersion between the gross premium collected on the market within group 14 - insurance was presented. loan and the average premium rate in trade credit insurance (figure 8).

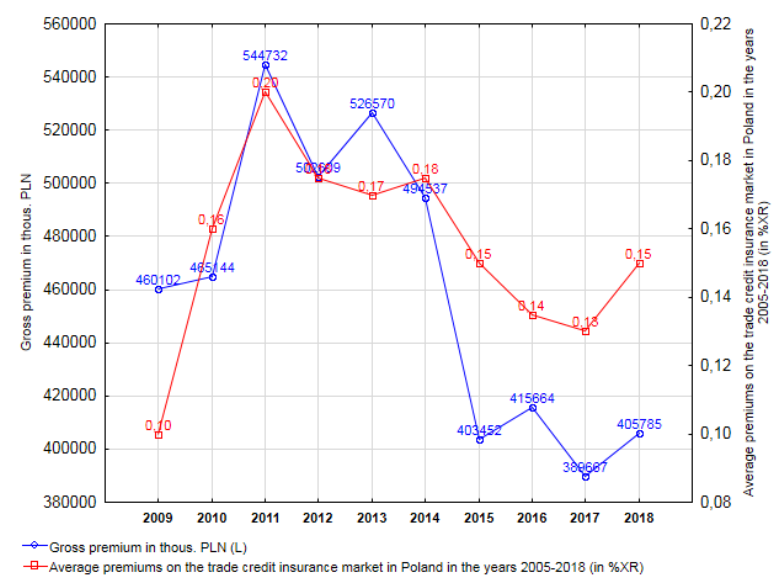

Figure 7. Gross premium and average premium rates in the trade credit insurance market

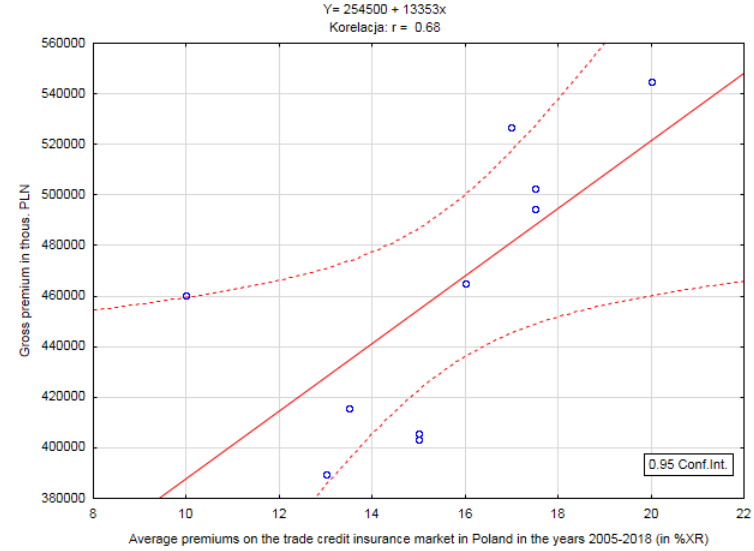

Figure 8. The dispersion between the gross premium in thous PLN and the average premium rate in the credit insurance market

Source: Author's own study based on data from the Polish Financial Supervision Authority and RiskMan.

It was checked whether there was a relationship between the gross written premium and the average premium rate in the trade credit insurance market. The correlation analysis shows that the dependence is high and amounts to 0.68 . The above indicates a positive relationship, directly proportional, and means that the gross premium written increases along with the growth in the average premium rate in the trade credit insurance market. In $68 \%$, the average rates model the gross premium. If the average rate increases by $1 \%$, the gross premium is PLN 13.353.000.

By means of the correlation analysis, it was checked whether there are connections between the gross written premium and the number of companies that declared bankruptcy in particular industries. The analysis shows that there was a correlation between gross written premium and the number of companies that declared bankruptcy in the construction industry. Spearman's rank correlation coefficient was 0.65 , which means a high degree of dependence between the variables. The relationship is positive, so with the increase in gross written premium, the number of companies declaring bankruptcy and operating in the construction industry grew. The features are modeling in $65 \%$. The relationship is statistically significant $\mathrm{p}<\alpha(\mathrm{p}=0.0425)$. The detailed results on the correlation between the gross written premium and average premiums for trade credit insurance and the number of companies that declared bankruptcy in individual industries per 100.000 companies operating in a given industry are presented in table 6 .

There is a moderate relationship between gross written premiums and companies that have filed for bankruptcy in the service sector. The relationship is negative, which means that with the increase in the gross premium in thous. PLN, the number of companies that have declared bankruptcy in the service sector is falling. The relationship is presented in the bag chart presented in figure 9 . 
Table 6

Correlation between the gross written premium and average premiums for trade credit insurance and the number of companies that declared bankruptcy in particular industries per 100.000 companies operating in a given industry

\begin{tabular}{|l|c|c|c|c|}
\hline & Gross premium written in thousand PLN & p-value & Average premium rates & p-value \\
\hline Construction & $\mathbf{0 . 6 5}$ & $0.0425^{*}$ & $\mathbf{0 . 7 7}$ & $0.0094^{* *}$ \\
\hline Production & 0.45 & 0.1869 & $\mathbf{0 . 3 0}$ & 0.4016 \\
\hline Services & $\mathbf{- 0 . 4 8}$ & 0.1615 & -0.17 & 0.6372 \\
\hline Retail & -0.22 & 0.5334 & 0.08 & 0.8276 \\
\hline Wholesale & 0.19 & 0.6032 & 0.30 & 0.4016 \\
\hline
\end{tabular}

Source: Author's own study based on data from the Polish Financial Supervision Authority and RiskMan.

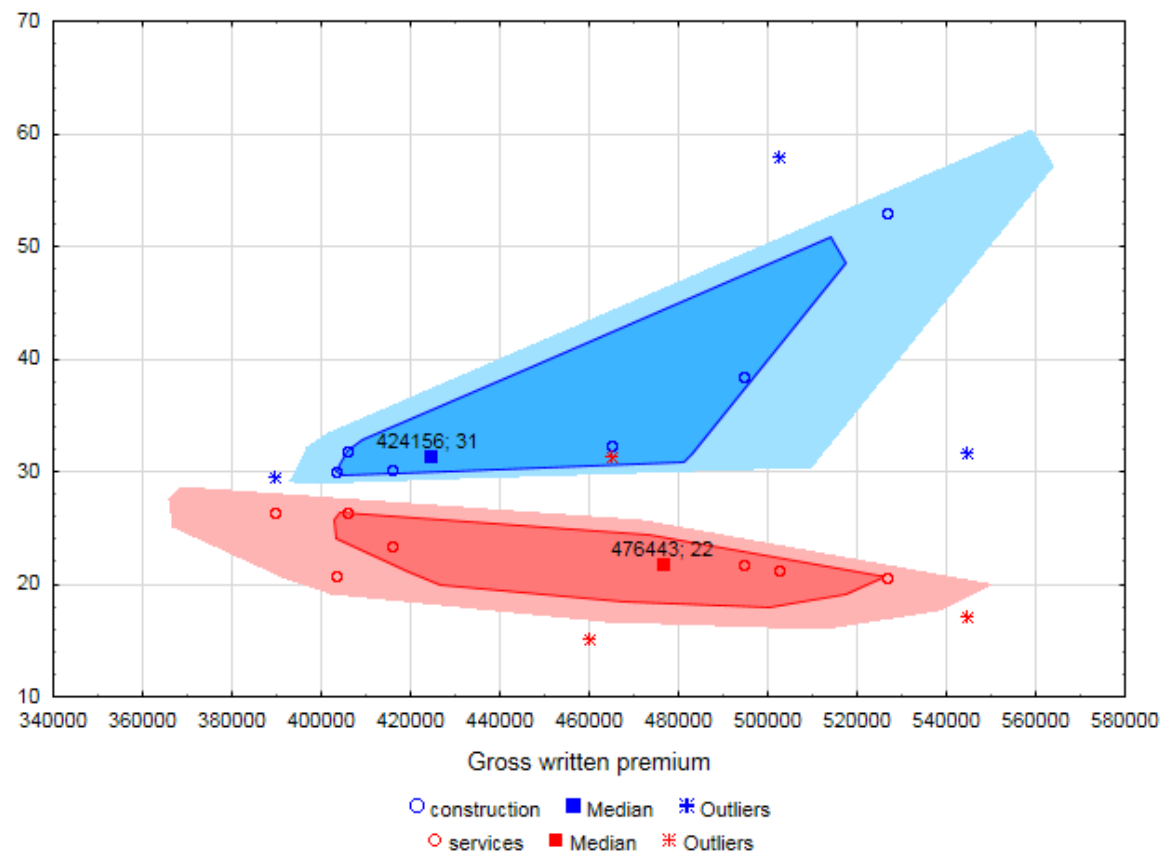

Figure 9. Bag plot between gross written premium and the number of companies that declared bankruptcy in construction and services per 100.000 companies operating in the analyzed industries

Source: Author's own study based on data from the Central Statistical Office and RiskMan

In the case of dependencies related to the average premium rate on the trade credit insurance market in Poland in 2009-2018, the largest correlation was again noted in relation to companies that declared bankruptcy in the construction industry. Spearman's rank correlation coefficient was 0.77 , which means a positive correlation, along with an increase in the rate, the number of companies that have declared bankruptcy in the construction industry per 100 thousand. companies operating in this sector. The relationship is significant. The features model themselves in $77 \%$.

There was a clear, but low correlation between the average premium rate on the trade credit insurance market and the number of companies that declared bankruptcy in the manufacturing industry. The correlation coefficient was 0.30 . It is also a positive correlation, along with an increase in the average rate on the trade credit insurance market, the number of companies that declared bankruptcy in the manufacturing sector increases. A bag plot showing the relationship between the average premium rate on 
the trade credit insurance market in Poland in 2009-2018 and the number of companies that declared bankruptcy in construction and production per 100.000 companies operating in these industries is presented in figure 10.

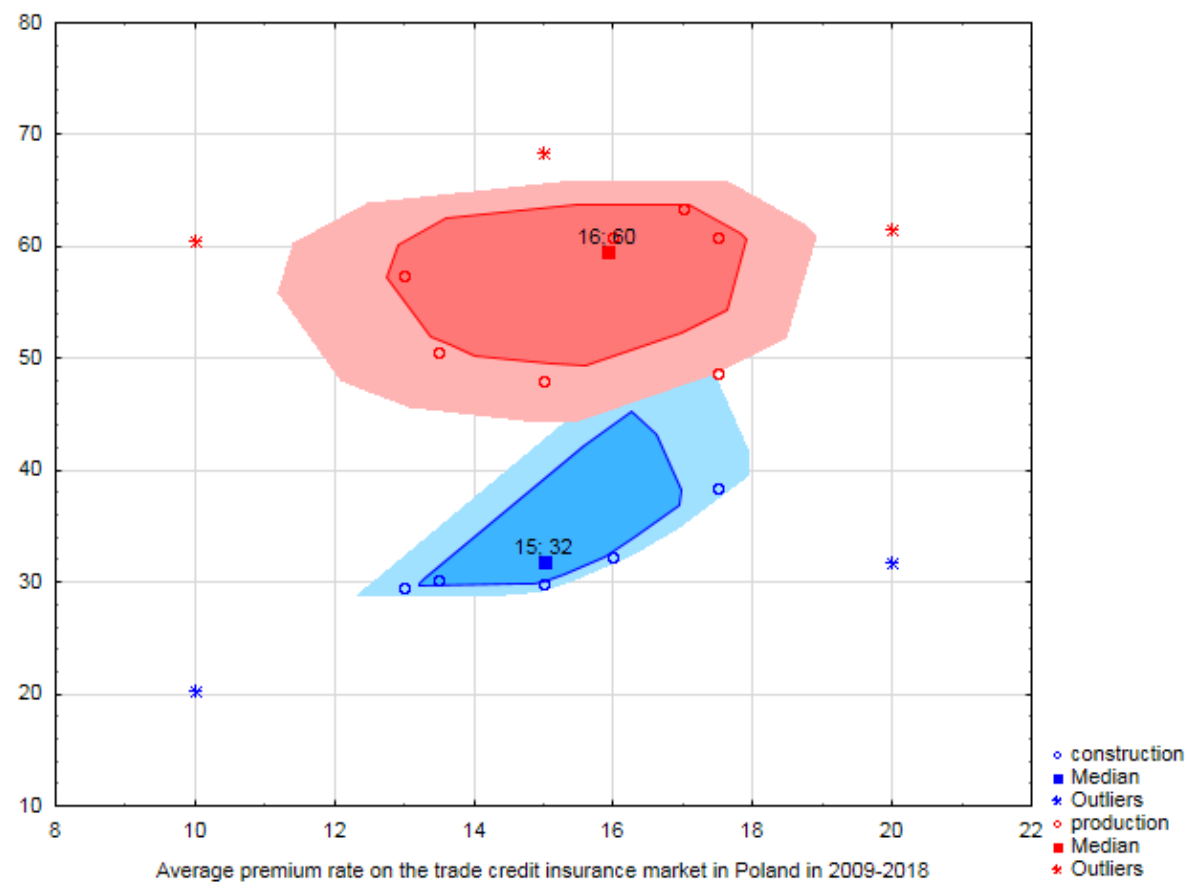

Figure 10. Bag plot between the average premium rate on the trade credit insurance market in Poland in 2009-2018 and the number of companies that declared bankruptcy in construction and production per 100,000 companies operating in the analyzed industries

Source: Author's own study based on data from the Central Statistical Office and RiskMan

\section{CONCLUSION}

According to the literature research, the risk of bankruptcy is one of the key types of risk that accompanies the business activity conducted by enterprises. The key fact is that the majority of commercial transactions are now carried out on the basis of trade credit, which is undoubtedly one of the most popular forms of short-term financing of enterprises around the world. At the same time, it is also a source of risk for entities involved in lending activities, which means that the risk of bankruptcy takes on a slightly different dimension. It turns out that when using a trade credit, any financial problems on the part of contractors, and in particular difficulties in paying off liabilities, may naturally translate into financial problems of the entity that grants the trade credit. Therefore, it is extremely important to conduct research on bankruptcy in the context of how companies finance their activities and how they can protect themselves against the risks resulting from the use of deferred payment terms.

The results of the empirical research conducted in Poland prove that the most cases of bankruptcy are recorded among companies from the manufacturing sector, and the least among companies dealing with retail sales. The research also showed the existence of links between the number of companies that failed in particular industries. It turns out that this relationship is very large in the case of companies operating in the manufacturing industry and wholesale. This means that the more companies that filed for bankruptcy in the manufacturing sector, the more went bankrupt in the retail sector, and a similar relationship occurred in the case of retail and service sales. 
From the point of view of the subject of this paper, the key conclusions are the ones regarding the relationship between the cost of trade credit insurance and corporate bankruptcy. The research proved that there were trends in the market that the gross premium written increased along with a growth in the average premium rate in the trade credit insurance market. Moreover, when analyzing the results of the research, a high level of dependence can be observed between the change in the amount of gross written premium for trade credit insurance and the number of bankruptcies in the construction sector. This means that along with an increase in the gross written premium, and also the average price of trade credit insurance, the number of bankruptcies reported among enterprises from the construction sector increased. Therefore, it can be seen that companies in this industry may be most affected by any change in the price of trade credit insurance. The reasons for this can be found in the fact that the trade credit is extremely widely used in the construction industry, which in turn translates into a higher risk of difficulties if creditors are not able to pay their liabilities on time. On the other hand, an increase in the costs of insurance protection may constitute a difficult to ignore barrier when it comes to the availability of enterprises in this industry to the possibility of securing their receivables with loan insurance. As a result of the above, an improvement in insurance costs may make it impossible for enterprises to use it, which in turn is related to the lack of protection against the risk of contractor's insolvency. In a pessimistic scenario, this may result in a much higher risk of bankruptcy than in a situation where the enterprise would use this form of protection.

\section{ACKNOWLEDGEMENT}

The article was financed entirely from funds from the Faculty of Management of the Rzeszow University of Technology.

\section{REFERENCES}

Agostino, M., \& Trivieri, F. (2019). Does Trade Credit Affect Technical Efficiency? Empirical Evidence from Italian Manufacturing SMEs, Journal of Small Business Management, 57(2), 576-592.

Aleksanyan, L., \& Huiban, J.P. (2016). Economic and Financial Determinants of Firm Bankruptcy: Evidence from the French Food Industry. Review of Agricultural, Food and Environmental Studies, 97, 89-108. doi:10.5539/ijef.v9n8p12

AON (2018). Raport Aon Polska, 5-6.

Bărbuță-Mişu, N. (2018). Analysis of factors influencing managerial decision to use trade credit in construction sector, Economic Research-Ekonomska Istraživanja, 31(1), 1903-1922, https://doi.org/10.1080/1331677X.2018.1504690

Bărbuț ă-Miș u, N., \& Madaleno, M. (2020). Assessment of Bankruptcy Risk of Large Companies: European Countries Evolution Analysis. Journal of Risk Financial Management, 13(58), 1-28. doi:10.3390/jrfm13030058

Bera, A. (2005). Ubeapieczenia finansowe jako instrument wspierajacy polityke kedytowa przedsiebiorstw wobec odbiorców. Warsaw. Fundacja „Warta”, 9-198.

Chod, J., Lyandres, E., Alex Yang, S. (2019). Trade Credit and Supplier Competition. Journal of Financial Economics, Elsevier, 131(2), 484-505. doi: 10.1016/j.jfineco.2018.08.008

Ciżkowicz-Pękała, M. (2017). Trade credit: a benefit to get, a "must" to give? Motives behind trade credit use in Poland. Financial Internet Quarterly ,e-Finanse”, 14(4), 55-56. doi: 10.1515/fiqf-2016-0035

Dankiewicz, R. (2020). Single cover as a supplement to the product offer of trade credit insurers used in risk management processes in enterprises. Int. J. Business Performance Management, 21(4), 402. doi:10.1504/IJBPM.2020.110807

García-Teruel, P.J., \& Martínez-Solano, P. (2010). Determinants of trade credit: a comparative study of European SMEs. Int. Small Bus. J., 28(3), pp. 215-233. doi:10.1177/0266242609360603

Gaspareniene, L., Remeikiene, R., Sadeckas, A., \& Chadyšas, V. (2019) A Preference for Corporate Borrowing in Alternative Markets over Borrowing from Banks under the Impact of Monetary Policies: a Lithuanian Case, Economic Research-Ekonomska Istrą̌ivanja, 32(1), 1903-1921, https://doi.org/10.1080/1331677X.2019.1638288 
Huang, L., Ying, Q., Yang, S., \& Hassan, H. (2019). Trade Credit Financing and Sustainable Growth of Firms: Empirical Evidence from China. Sustainability, 11(4), 1-20. doi:10.3390/su11041032

International Credit Insurance \& Surety Association (ICISA) (2015). A Guide to Trade Credit Insurance. New York, Anthem Press, 1-131.

Juan Grau, A., \& Reig, A. (2018). Trade credit and determinants of profitability in Europe. The case of the T agri-food industry. International Business Review, 27, 947-957. doi: 10.1016/j.ibusrev.2018.02.005

Khan, Ajaz, K., Dankiewicz, R., Kliuchnikava, Y., \& Oláh, J. (2020). How Do Entrepreneurs Feel Bankruptcy? International Journal of Entrepreneurial Knowledge, 8(1), 89-101. doi:10.37335/ijek.v8i1.103

Kliestik, T., Valaskova, K., Lazaroiu, G., Kovacova, M., \& Vrbka, J. (2020). Remaining financially helathy and competitive: The role of financial predictors. Journal of Competitiveness, 12(1), 74-92. doi: 10.7441/joc.2020.01.05

Kovacova, M., Kliestik, T., Valaskova, K., Durana, P., \& Juhaszova, Z. (2019). Systematic review of variables applied in bankruptcy prediction models of Visegrad group countires. Oeconomia Copernicana, 10(4), 743-772. doi: 10.24136/oc.2019.034

Kowalczyk-Rólczyńska, P. (2013). Ubezpieczenie jako instrument transferu ryzyka ubezpieczeniowego. Zarzqdz̧anie $i$ Finanse, 2(5), 79.

Kristanti, F. T., Rahayu, S., \& Isynuwardhana, D. (2019). The survival of small and medium business. Polish Journal of Management Studies, 20(2), 311-321. https://doi.org/10.17512/pjms.2019.20.2.26

Kücher, A., Mayr, S., Mitter, C., Duller, C., \& Feldbauer-Durstmüller, B. (2020), Firm age dynamics and causes of corporate bankruptcy: age dependent explanations for business failure. Review of Managerial Science, 14, 656-658. doi:10.1007/s11846-018-0303-2

Kumaraswamy, S., \& George, S. (2019). Trade credit management and firm profitability of Saudi manufacturing firms. Polish Journal of Management Studies, 20(1), 243-253. doi:10.17512/pjms.2019.20.1.22

Kwiecień, I. (2010). Ubezpieczenie jako metoda zarzqadzania ryzykkiem w džiałalności gospodarczej, Warszawa. CH Beck.

Lezgovko, A., \& Jakovlev, A. (2017). The Evaluation of Trade Credit Insurance in Lithuanian Business Market as a Credit Risk Management Tool. Economics and Culture, 14(1). doi:10.1515/jec-2017-0001

Lisowski, J. (2014). Trade credit insurance - specifity of risks. Insurance Review, 4, 19-27.

Lukason, O. \& Camacho-Miñano, M. (2019). Bankruptcy Risk, Its Financial Determinants and Reporting Delays: Do Managers Have Anything to Hide?. Risks, 7(77), 1-15. doi:10.3390/risks7030077

Mackevičius, J., Šneidere, R., Tamulevičienè, D. (2018). The waves of enterprises bankruptcy and the factors that determine them: the case of Latvia and Lithuania. Entrepreneurship and Sustainability Issues, 6(1), 111-112. doi:10.9770/jesi.2018.6.1(8)

Mainardes, E.W., Lopes Mota, R., Cardoso Moreira, N. (2020). The effect of corporate bankruptcy reorganization on consumer behaviour. European Research on Management and Business Economics, 26, 96-102. doi:10.1016/j.iedeen.2020.03.002

Pattnaik, D., Hassanb, M.K., Kumara, S., Paul, J. (2020). Trade credit research before and after the global financial crisis of 2008 - A bibliometric overview. Research in International Business and Finance, 54, 1-24. doi:10.1016/j.ribaf.2020.101287

Petersen, M. \& Rajan, R. (1997). Trade credit: theories and evidence. Review of Financial Studies, 10, 661-691. doi:10.1093/rfs/10.3.661

Peura H., Yang S.A., Lai G. (2017). Trade Credit in Competition: A Horizontal Benefit. Manufacturing \& Service Operations Management, 19(2), 263-289. doi:10.1287/msom.2016.0608

Piesse, J., Lee Lin, Ch., Lee, A. (2006). Corporate failure: Definitions, methods, and failure prediction models [in:] Encyclopedia of Finance, Chapter 22, 477-455, Boston, Springer.

Pirttilä, M., Virolainen, V.M., Lind, L., Kärri, T. (2019). Working capital management in the Russian automotive industry supply chain. Int. J. Prod. Econ., 221(107474). https://doi.org/10.1016/j.ijpe.2019.08.009.

Pointer, L., \& Khoi, P.D. (2019). Predictors of Return on Assets and Return on Equity for Banking and Insurance Companies on Vietnam Stock Exchange. Entrepreneurial Business and Economics Review, 7(4), 185-198. https://doi.org/10.15678/EBER.2019.070411

Polat, A. \& Yeșilyaprak, M. (2017). Export Credit Insurance and Export Performance: An Empirical Gravity Analysis for Turkey. International Journal of Economics and Finance, 9(2), 20. 
Prasad, S. (2016). The efficacy of credit insurance. A study of the quantitative Impact on trade receivables and receivables Turnover ratio. BBA International Business, 49-50.

Redo, M. (2013). The growing importance of the risk-taking channel in the process of transmitting monetary policy. Torun International Studies, 1(6), 13-22. https://dx.doi.org/10.12775/TIS.2013.002

Redo, M., \& Siemiatkowski, P. (2017). Financial security of the state. Torun: Wydawnictwo Naukowe UMK. https://dx.doi.org/10.12775/TIS.2017.100

Siciński, J. (2019). Macroeconomic determinants of corporate failures in Poland. Contemporary Economy Electronic Scientific Journal, 12(2), 10-11. doi:10.26881/wg.2019.2.02

Stakanov, R., \& Ukhova, A. (2020). Digitization and robotization of the world economy as a key determinant of the international labor market transformation. Torun International Studies, 1(13), 93-104. https://dx.doi.org/10.12775/TIS.2020.007

Staszkiewicz, P., \& Szelagowska, A. (2019). Ultimate owner and risk of company performance, Economic ResearchEkonomska Istraživanja, 32(1), 3795-3812, https://doi.org/10.1080/1331677X.2019.1678499

Van Horen, N. (2004). Trade Credit as a Competitiveness Tool: Evidence from Developing Countries. MPRA Paper, No. 2792 2004, 1-25.

Wajda-Lichy, M., \& Kawa, P. (2018). Trade-Finance Nexus: Was it Distorted in the Aftermath of the Global Financial Crisis?. Entrepreneurial Business and Economics Review, 6(3), 11-27. https://doi.org/10.15678/EBER.2018.060301

Wojcik, P., \& Ciszewska-Mlinarič, M. (2020). Explorative and exploitative choices in response to initiative failure: Study of entrepreneurs and managers. Entrepreneurial Business and Economics Review, 8(3), 83-99. https://doi.org/10.15678/EBER.2020.080305

Xing, M. (2019). Strategic R\&D risk choices of public and private firms, Economic Research-Ekonomska Istrą̌ivanja, 32(1), 717-741, https://doi.org/10.1080/1331677X.2019.1578679 